\title{
Twelfth Addenda to Criticism of the Current Science in the World
}

Pejman Malekinejad"

Department of Materials Science and Engineering, Kerman Graduate University of Technology, Iran

Article History

Received: 09.12.2020

Accepted: 20.12.2020

Published: 23.12 .2020

Journal homepage:

https://www.easpublisher.com
Abstract: In this article, some scientific problems of Iran were mentioned. It was concluded that Iran and I will not become anything in the science, I have no intelligence and Iran and I will not become anything in general. Therefore, according to the principles of DEPRESSIVE REALISM, I must always be happy. In addition, it was deduced that the only way for the scientific advancement of Iran is to make Iran a state of USA. Keywords: Schizophrenia, DEPRESSIVE REALISM, Industry, University.

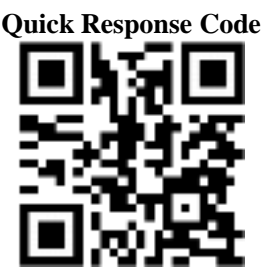

Copyright (C) 2020 The Author(s): This is an open-access article distributed under the terms of the Creative Commons Attribution 4.0 International License (CC BY-NC 4.0) which permits unrestricted use, distribution, and reproduction in any medium for non-commercial use provided the original author and source are credited.

\section{INTRODUCTION}

Voice of America (VOA Persian) has issued an article [1] that is in the same line with this paper. In fact, that article from VOA Persian confirms this paper. Also Eminent Crown Prince of Iran, Reza Pahlavi has a saying from Atamalek Joveini about Iran Islamic Regime as "They came and dug and burned and killed and took away and went" [2] which approves this paper.

\section{DISCUSSION}

I have previously said that a large part of discovered science is kept secret and is not in public access [3 to 15]. This fact was first given by my university professor Mohammad Jamialahmadi whose resume can be found in internet [16]. He was known as the scientific pole of the university and repeated this fact many times and for all the students in the classroom but no one understood it because it was very heavy. This fact is exactly mentioned in "Encyclopedia of World Problems and Human Potential [17]" as "A considerable amount of scientific research is conducted in institutes or under contracts which preclude dissemination of the results to other than a select group [18]". Therefore, we can see that Iran cannot solve many scientific problems as superpowers.

The age of Iran oil industry is more than 100 years [19]. Also the age of Iran universities are more than 90 years [20]. Furthermore, the age of Petroleum University of Technology in Iran is more than 80 years [21]. But as I have illustrated in my previous papers [3 to 15], Iran oil industry is not independent. Then the question which arises is that what did the Iran universities do during these great periods of times? It can be concluded that universities in Iran are waste of time and in the case of Iran are established to make people busy with science for them not to think of important things like politics. Iranians claim that by counting the number of ISI papers, Iran stood in the $16^{\text {th }}$ ranking for production of science worldwide [22]. Apparently, it seems that ISI papers change the rules of the world. But in reality, ISI papers are not reliable since most of them are fake data makings. What's more, a large part of discovered science is kept secret and is not presented to public for ranking [18]. Changing the rules of the world is not easy because these rules are scientific. Undoubtedly Iranians cannot change the rules of the world. As an activity in universities, ISI papers in Iran are waste of time and in the case of Iran are established to make people busy with science for them not to think of important things like politics. ISI journals do not publish single author articles and this is because the principles of DEPRESSIVE REALISM rule for publication in ISI journals. Multiple author articles show that a number of people worked together to write ISI article and none of them could scientifically write such article alone. But single author articles show that 
the author is scientifically very strong who could write article alone and this causes jealousy in journals and in people. Currently Iranian film makers immigrate to advanced countries and want to play roles in superpower cinemas to say that they are very great. But it should be noted that Iran cinema needs much work to reach the superpowers cinemas. For example, if one looks at the worldwide top box office movies [23], then he will find that Iranian movies are not money making at all and do not lie within top 276 movies of 2019 for example in the world who make money. If Iranian film makers claim that they are great, then they should stay in Iran and make Iran cinema great. In the same way, I have previously criticized the brain drain phenomena from Iran [8]. If those brains who escape from Iran were so great, then they should stay in Iran and solve Iran scientific problems.

Also Hollywood is full of movies about DEPRESSIVE REALISM. At one end, there are movies like "The Silence of the Lambs, 1991", "Rain Man, 1988", "A Beautiful Mind, 2001”, "The Iron Lady, 2011" and etc. In these movies intelligent people got mental disorders according to the principles of DEPRESSIVE REALISM. The message of great movie of "The Silence of the Lambs, 1991" is that if you do not understand anything like a lamb, then you will be slaughtered. At the other end, there are animations like "Droopy, 1943" which show that application of the principles of DEPRESSIVE REALISM causes the society not to advance. In summary in this animation, Droopy dog is in competition with other larger, more intelligent, more active and stronger dogs and in all these competitions, the droopy dog wins according to the principles of DEPRESSIVE REALISM. An episode of such type can be seen in YouTube [24, 25 and 26]. Therefore, their society will never advance and they will remain animal forever and will never become humans. Anyway I laugh very much when watching this animation. Droopy is an animated character from the golden age of American animation. The very iconic quote of Droopy Dog is "I'M SO HAPPY" which is clear in Figure 1. In one of episodes of this animation called "Blackboard Jumble" [27], droopy dog tries to make mental disorder for his teacher because he is jealous of the teacher science. One concept that the teacher taught to droopy and caused his jealousy was $3=3$ which was written on the blackboard. The behavior of this teacher after catching mental disorder is very similar to me. The "Sadder but Wiser" effect or DEPRESSIVE REALISM principles can be truly seen in Iranian society since the official news agency of TABNAK officially says that Iranian managers employ weak people [28]. TABNAK news agency is approved by Iran government. However, life like an animal is not valuable at all.

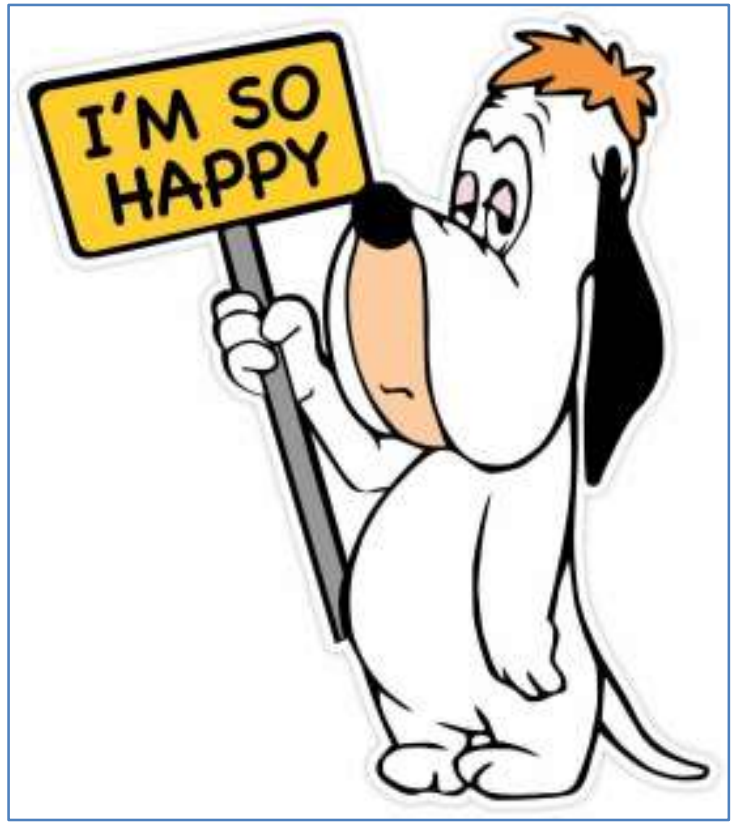

Fig-1: Droopy Dog with its iconic quote.

People think that I am the world mastermind and therefore all the people try to make mental disorder for me. I want to tell that I am not the mastermind of the world and I will not become so. Therefore, according to the principles of DEPRESSIVE REALISM, I must get happy.

Fig. 2 is from BABYLON PICTURE DICTIONARY for crazy. He spins his finger around his ear to say that you are crazy. Also, he mocks everybody. He escapes since the people make him crazy. He uses magic to produce illusions and hallucinations. BABYLON PICTURE DICTIONARY is a valid, reputable and top international dictionary. Now I suppose that you could send me to madhouse. But the world understands that you, yourself are crazy. The following photo from BABYLON PICTURE DICTIONARY shows this fact very good. According to the principles of DEPRESSIVE REALISM, the reason why intelligent people catch mental disorders is that all the people are jealous of such minds and therefore try to make a mental disorder for those intelligent persons and try to destroy those minds. This is because people think that everything is brain and science and they are the most important things. The people think that if they have brain and science, then they will reach everything. This is completely wrong in Iran since the most important thing is politics in Iran because money, power and other benefits of political activities is extremely higher than any other activities in Iran. For example, as I have previously mentioned [29], the worth of Khamenei as Iran leader (200 Billion USD) is approximately twice more than the worth of richest person in the world as Mr. Jeff Bezos (116.9 Billion USD) who is known as the founder of AMAZON as world giant technology company [30]. Furthermore, Khamenei has control of Iran military and for example guns, missiles, war aircrafts, bombs and so on which 
Mr. Jeff Bezos does not have them. People cannot withstand and bear that a brain works so well and try to make a mental disorder for that intelligent person. It is to say that the intelligent people are mentally ill and in this way they appear crazy. These mental disorders are made to show that intelligent people seem crazy. People make mental disorders for intelligent persons to say that do not be honored of your brain since the psychological facts show that you have a mental disorder. But all the world knows that those who make these mental disorders are crazy themselves. People want to make psychiatric and medical documents, dossiers and records for that genius to show that he is mentally ill and this is why they send him to psychiatrist. The age of such frauds is over. The following photo from BABYLON PICTURE DICTIONARY shows this fact very good. Beside political reasons, one reason why I have written this article and my previous papers [3 to 15] was to say that I will not become anything in the science, I have no intelligence and I will not become anything in general. This is because a large part of discovered science is kept secret and is not in my and public access [18]. Therefore, do not be jealous of me, my science and my brain. So, I must be happy according to the principles of DEPRESSIVE REALISM. Anyway the people say that I have schizophrenia and my manuscripts of psychiatrist are in my website [31 and 32]. In Farsi crazy means giant. But I am not giant at all and I have illustrated this fact here in this paper and my previous papers [3 to 15]. Being giant results in jealousy of others and causes mental disorders. In this world that everything is scientific, intelligent people are considered as giant people. 15 years ago my brother said to me that people want to make medical and psychiatric documents, dossiers and record for you and that you should not continue education since your schizophrenia will worsen. My brother is a physician and now is an orthopedist. Now I understand him. I mean that there are greater psychiatrists than me in the world. Since everybody wants to make mental disorder for me, then it can be concluded that I am the mastermind of the world. Crazy people make mental disorders for people since they are jealous of others' science. But do not be jealous of my mind, my science and me since I am nothing. I have published 13 articles in international journals [3 to 15] in which in summary I have said that I will not become anything in the science, I have no intelligence and I will not become anything in general. Therefore, according to principles of DEPRESSIVE REALISM, I must always be happy. So do not get crazy and consequently make me happy. The following photo is BABYLON PICTURE DICTIONARY for CRAZY.

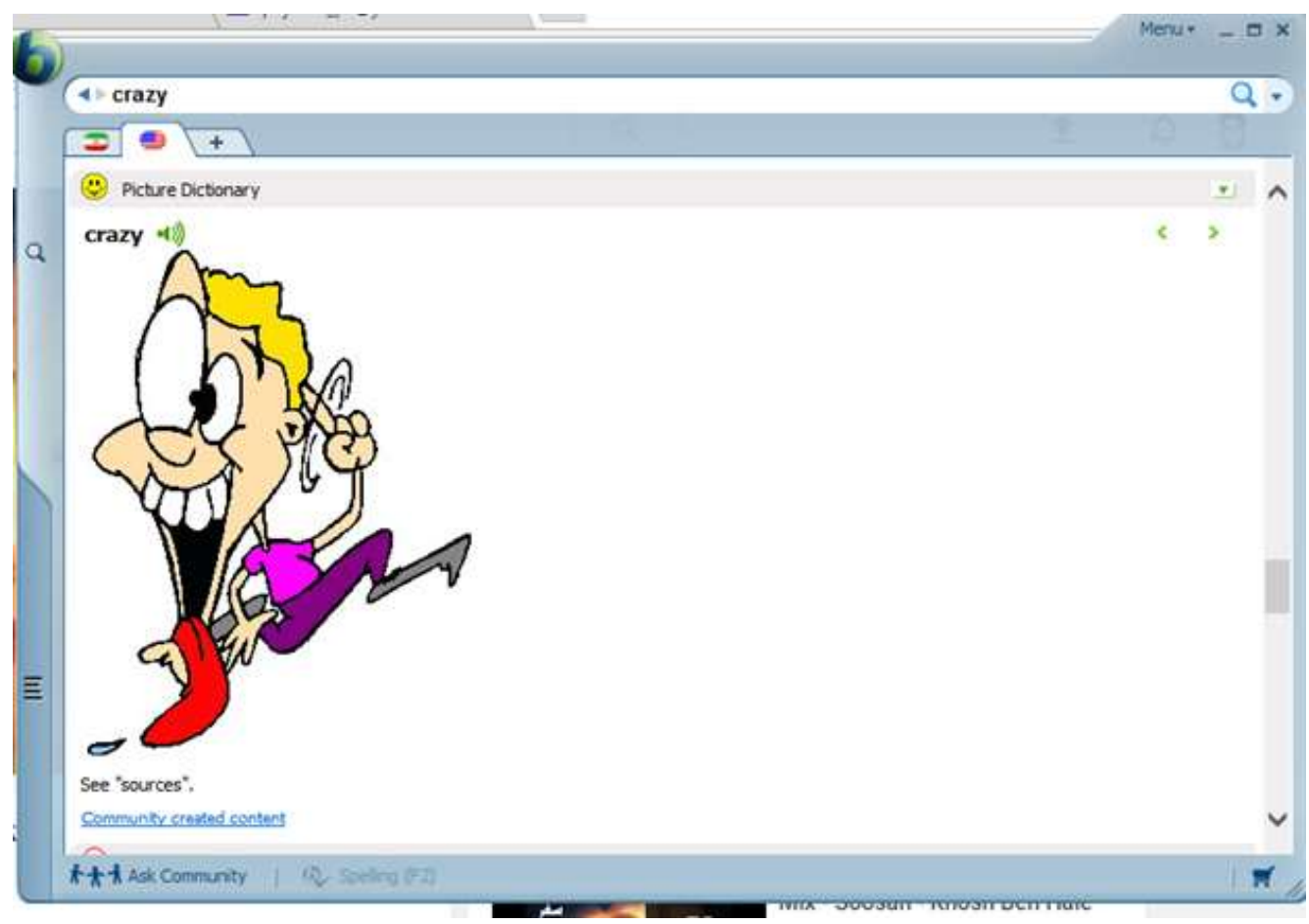

Fig-2: Babylon picture dictionary for crazy

According to the principles of DEPRESSIVE REALISM, sadder people are wiser. On the other hand, crazy people are happy. This happiness is not free and it has a cost. The cost is that one should always remain crazy. I will continue writing these series of papers titled "Criticism of the Current Science in the World" and "Its Addenda" [3 to 15] forever. I love and respect
USA, UK and Israel. Also I will continue my political activity forever. I am proud of my political activity. I had the greatest honors of my life at the time of presidency of Dear Eminent Mr. President of USA Donald J. Trump. I was selected as TOP FAN in FACEBOOK pages of Dear Eminent Mr. President of USA Donald J. Trump, Her Highness Mrs. Ivanka 
Trump, U.S. VIRTUAL EMBASSY IRAN and other famous people and organizations [33, 34 and 35]. Also we had significant progresses in changing the behavior of Iran governments as a result of USA sanctions against Iran regime. As a result, Iranian money will be spent more inside of Iran instead of Syria, Iraq, Lebanon, Palestine, Yemen and etc. Also thanks a lot for Dear Eminent Mr. President of USA Donald J. Trump support from Iranian political activists and Iranian people protests against Iran governments. Also thanks a lot to Dear Eminent Mr. President of USA Donald J. Trump for bringing peace to middles east by making peace deals between Israel, UAE and Kingdom of Bahrain. The COVID-19 vaccine will soon come for use as a result of Dear Eminent Mr. President of USA Donald J. Trump efforts. Dear Eminent Mr. President of USA Donald J. Trump services to mankind are countless. Also I used the thoughts and politics of Dear Eminent Mr. President of USA Donald J. Trump and Her Highness Mrs. Ivanka Trump in my articles which were significant. As I have mentioned in my articles, Dear Eminent Mr. President of USA Donald J. Trump will be the greatest USA and world politician ever. These articles of mine are accessible in my website [36] and were published in international journals.

I am a sick and very poor man. I requested Dear Eminent Mr. President of USA Donald J. Trump, Her Highness Mrs. Ivanka Trump and U.S. VIRTUAL EMBASSY IRAN to send me money. I know that they control many charity organizations worldwide. I need a monthly basic income to survive. I have created a WebMoney (WebMoney is an online payment settlement system) account for financial aid to receive. The purse number is $\mathrm{Z} 291871883734$ and is in my name. Financial aid from any other sources are also greatly appreciated. For financial helps from Iran, my card number in TEJARAT BANK is 5859831150971751 .

\section{Conclusion}

The only way that I strongly suggest for the scientific and economic advancement and development of Iran in all fields (including politics) is to make, regard and announce Iran as a state of USA (United States of America) officially and politically (and totally). I.e. Iran should make and regard itself as a state of USA (United States of America) politically (and totally). I have heard that this idea was first suggested by His Majesty Mohammad Reza Shah Pahlavi for Iran. I have created a petition in internet [37] for everybody to sign it and to make Iran a state of USA. So please sign this petition.

\section{REFRENCES}

1. https://ir.voanews.com/a/iran-sepahmilitary/3933992.html

2. http://www.iran-resist.org/article5591.html
3. Pejman, M. (2017). Criticism of the Current Science in the World. Oil Gas Res, 3(141), 24720518.

4. Malekinejad, P. (2018). Addenda to Criticism of the Current Science in the World. Stainless Steel, 6, 31.

5. Malekinejad, P. (2018). Second Addenda to Criticism of the Current Science in the World. International Journal of Recent Engineering Research and Development (IJRERD), ISSN, 2455-8761.

6. Malekinejad, P. (2018). Third Addenda to Criticism of the Current Science in the World. International Journal of Engineering, Business and Management, Open Access, ISSN, 2456-7817.

7. Malekinejad, P. (2020). Seventh Addenda to Criticism of the Current Science in the World. Glob Acad J Humanit Soc Sci, 2, 6-10.

8. Malekinejad, P. (2018). Third Addenda to Criticism of the Current Science in the World. International Journal of Engineering, Business and Management, Open Access, ISSN, 2456-7817.

9. Pejman, M. (2019). "Fourth Addenda to Criticism of the Current Science in the World", Scholars Journal of Arts, Humanities and Social Sciences, 7(7), 474-481.

10. Malekinejad, P. Criticism of the Current Science in the World. Oil and Gas Research, Open Access, OMICS International.

11. Malekinejad, P. (2020). Seventh Addenda to Criticism of the Current Science in the World. Glob Acad J Humanit Soc Sci, 2, 6-10.

12. Malekinejad, P. (2020). Seventh Addenda to Criticism of the Current Science in the World. Glob Acad J Humanit Soc Sci, 2, 6-10.

13. Malekinejad, P. Eighth Addenda to Criticism of the Current Science in the World. International Journal of Research in Humanities, Arts and Literature (IMPACT: IJRHAL), OPEN ACCESS, ISSN (Print), 2347-4564.

14. Malekinejad, P. Eighth Addenda to Criticism of the Current Science in the World. International Journal of Research in Humanities, Arts and Literature (IMPACT: IJRHAL), OPEN ACCESS, ISSN (Print), 2347-4564.

15. Malekinejad, P. Twelfth Addenda to Criticism of the Current Science in the World.

16. https://www.facebook.com/TrbtJam/posts/7859992 38186679

17. http://encyclopedia.uia.org/en

18. http://encyclopedia.uia.org/en/problem/136232

19. https://fa.wikipedia.org/wiki/\%D8\%B5\%D9\%86\% D8\%B9\%D8\%AA_\%D9\%86\%D9\%81\%D8\%AA \%D8\%A7\%DB\%8C\%D8\%B1\%D8\%A7\%D9\%86

20. https://fa.wikipedia.org/wiki/\%D8\%A2\%D9\%85\% D9\%88\%D8\%B2\%D8\%B4 \%D8\%B9\%D8\%A7\% D9\%84\%DB\%8C \%D8\%AF\%D8\%B1 \%D8\%A7 \%DB\%8C\%D8\%B1\%D8\%A7\%D9\%86 
21. https://en.wikipedia.org/wiki/Petroleum_University of Technology

22. https://www.isna.ir/news/95102012400/\%D8\%B1 $\% \mathrm{D} 8 \% \mathrm{AA} \% \mathrm{D} 8 \% \mathrm{~A} 8 \% \mathrm{D} 9 \% 87-$ $\% \mathrm{D} 8 \% \mathrm{~B} 3 \% \mathrm{D} 9 \% 88 \% \mathrm{D} 9 \% 85-$ \%D8\%A7\%DB\%8C\%D8\%B1\%D8\%A7\%D9\%86$\% \mathrm{D} 8 \% \mathrm{AF} \% \mathrm{D} 8 \% \mathrm{~B} 1-$ $\% \mathrm{D} 8 \% \mathrm{~B} 4 \% \mathrm{D} 8 \% \mathrm{AA} \% \mathrm{D} 8 \% \mathrm{~A} 7 \% \mathrm{D} 8 \% \mathrm{~A} 8-$ $\% \mathrm{D} 8 \% \mathrm{~B} 9 \% \mathrm{D} 9 \% 84 \% \mathrm{D} 9 \% 85 \% \mathrm{DB} \% 8 \mathrm{C}-$ $\% \mathrm{D} 8 \% \mathrm{AF} \% \mathrm{D} 8 \% \mathrm{~B} 1-$ \%D9\%85\%DB\%8C\%D8\%A7\%D9\%86-25$\% \mathrm{DA} \% \mathrm{~A} 9 \% \mathrm{D} 8 \% \mathrm{~B} 4 \% \mathrm{D} 9 \% 88 \% \mathrm{D} 8 \% \mathrm{~B} 1-$ $\% \mathrm{D} 8 \% \mathrm{AA} \% \mathrm{D} 9 \% 88 \% \mathrm{D} 8 \% \mathrm{~B} 3 \% \mathrm{D} 8 \% \mathrm{~B} 9 \% \mathrm{D} 9 \% 87-$ \%DB\%8C\%D8\%A7\%D9\%81\%D8\%AA\%D9\%87 $=$ $\% \mathrm{D} 8 \% \mathrm{AC} \% \mathrm{D} 8 \% \mathrm{~A} 7 \% \mathrm{DB} \% 8 \mathrm{C} \% \mathrm{DA} \% \mathrm{AF} \% \mathrm{D} 8 \% \mathrm{~A}$ 7\%D9\%87

23. https://www.the-numbers.com/box-officerecords/worldwide/all-movies/cumulative/releasedin-2019

24. https://www.youtube.com/watch? $\mathrm{v}=\mathrm{mlrbq}-\mathrm{VzcoM}$

25. https://www.youtube.com/watch?v=0O3sHOpYh1 $\underline{Y}$

26. https://www.youtube.com/watch?v=4D9tjSXtXiI

27. https://www.youtube.com/watch?v=TOh1ssRiOok

28. https://www.tabnak.ir/fa/news/256978/\%DA\%86\% D8\%B1\%D8\%A7-

\% $9 \% 85 \% \mathrm{D} 8 \% \mathrm{AF} \% \mathrm{DB} \% 8 \mathrm{C} \% \mathrm{D} 8 \% \mathrm{~B} 1 \% \mathrm{D} 8 \% \mathrm{~A} 7$ $\% \mathrm{D} 9 \% 86-$ \%D8\%A7\%DB\%8C\%D8\%B1\%D8\%A7\%D9\%86 $\% \mathrm{DB} \% 8 \mathrm{C}-$
\%D8\%A7\% D9\%81\%D8\%B1\%D8\%A7\%D8\%AF\%D9\%85\%D8\%B7\%DB\%8C\%D8\%B9$\% \mathrm{D} 9 \% 88-$

\%D8\%B6\%D8\%B9\%DB\%8C\%D9\%81$\% \mathrm{D} 8 \% \mathrm{~B} 1 \% \mathrm{D} 8 \% \mathrm{~A} 7-$ $\% \mathrm{D} 8 \% \mathrm{~A} 8 \% \mathrm{D} 8 \% \mathrm{~B} 1 \% \mathrm{D} 8 \% \mathrm{~A} 7 \% \mathrm{DB} \% 8 \mathrm{C}$ $\% \mathrm{D} 9 \% 87 \% \mathrm{D} 9 \% 85 \% \mathrm{DA} \% \mathrm{~A} 9 \% \mathrm{D} 8 \% \mathrm{~A} 7 \% \mathrm{D} 8 \% \mathrm{~B} 1$ $\% \mathrm{DB} \% 8 \mathrm{C}-$

$\% \mathrm{D} 8 \% \mathrm{~A} 8 \% \mathrm{D} 8 \% \mathrm{~B} 1 \% \mathrm{D} 9 \% 85 \% \mathrm{DB} \% 8 \mathrm{C} \% \mathrm{E} 2 \% 80$ \%8C\%DA\%AF\%D8\%B2\%DB\%8C\%D9\%86\%D9 $\% 86 \% \mathrm{D} 8 \% \mathrm{AF}$

29. https://ir.voanews.com/a/us-iran-/4893902.html

30. https://www.investopedia.com/articles/investing/01 2715/5-richest-people-world.asp

31. https://static.secure.website/wscfus/9883580/25558 915/psychiatrist2.jpg

32. https://static.secure.website/wscfus/9883580/25558 914/psychiatrist1.jpg

33. https://files.secure.website/wscfus/9883580/262073 09/president.pdf

34. https://static.secure.website/wscfus/9883580/25634 289/topen-new.pdf

35. https://static.secure.website/wscfus/9883580/25902 153/sefarat.pdf

36. https://pejmanmalekinejad.webstarts.com/

37. https://www.change.org/p/people-make-iran-astate$\underline{\text { ofusa? }}$ redirect=false $\&$ fbclid=IwAR11TU290rzKjoz 6wXNNsQgeW19R_cfrn_LL_lgdAC7yxk_ylj1cChZi Q 